\title{
Ideology, Alienation and Reification: Concepts for a Radical Theory of Communication in Contemporary Capitalism
}

\author{
Leila Salim Leal
}

Federal University of Rio de Janeiro, Rio de Janeiro, Brazil, leilasalimleal@yahoo.com.br

\begin{abstract}
Contemporary capitalism and its dynamics increase the material and ideological role played by the media, building a kind of sociality in which symbolic production becomes abundant. The critique of contemporary capitalism and the praxis to build alternatives to this form of society need to be put in the centre of debating cultural production. Cultural production interacts with the media and the market so that this symbolic field constitutes an increasingly predominant factor in the processes of the formation of consciousness. This instigates us to think about resistance as being necessarily linked to communication and culture. This article discusses the role of Marx's concepts of ideology and alienation for the constitution of a contemporary critique of the processes of the formation of consciousness.
\end{abstract}

Keywords: contemporary capitalism, communication, alienation, ideology, class struggle

\section{Contemporary Capitalism and Communication: Media, Markets and Con- sciousness}

From our point of view, to think of a radical theory of communication nowadays means to advance the critical investigation of the role and meaning of symbolic production in its various manifestations that are mediated with the specific material conditions of contemporary capitalism. Therefore, one needs to approach symbolic production with the category of totality and to reflect critically on the relations of symbolic production, overdetermination and contemporary capitalist society. This seems necessary for developing a communication theory that is not restricted to symbolic appearances (and thus does not limit itself to considering representations as "thing-initself", ignoring the importance of material relations of production and life reproduction for its consolidation) and, at the same time, does not leave out the complex mediations that constitute it (thus overcoming a mechanistic approach that reduces the understanding of everything symbolic to mere representations of material determination).

Consequently, to understand the dialectic of the symbolic nature and the social relations of production is a major starting point for a theoretical elaboration that analyses the complexities of the various communicational phenomena in our historical moment. A radical theory of communication also means understanding that such efforts need to be connected to the development of alternatives to capitalism and thus to the social struggles that develop in (and against) this form of social organisation. Understanding the dialectical character of the interactions established between the symbolic nature and the material relations of production, therefore, is of fundamental importance for the analysis of contemporary society's totality that aims to understand the role, meaning and potential of symbolic struggles for the development of alternative/emancipatory projects and the struggles that unfold as part of them. 
This article discusses the key elements occupied by communication in capitalism's ideological and material reproduction. One can use Marxist concepts (such as alienation) to think about the formation of consciousness and worldviews in the context of the culture industry. In the same vein, this reflection also uses the notions of ideology, alienation and reification for analysing the relationship between contemporary social movements and communication.

In order to think about the kind of capitalism that we are living in today, let us begin with an observation by José Paulo Netto in his afterword to the new edition of O Estruturalismo e a Miséria da Razão (Structuralism and the Misery of Reason), a crucial book by Carlos Nelson Coutinho, who reaffirms the need to understand contemporary capitalism's particularities as a form of society that rules the world and evolves by bringing about new phenomena, thus requiring analytical tools capable of responding to new developments. One should not ignore the transformations that capitalism has undergone since the 1970s and, consequently, the need for theoretical approaches that can account for such transformations:

Capitalism cannot be considered theoretically as it was understood until the 1970s: new problems, new questions and new alternatives come into its reality. But it is necessary to emphasize emphatically that it is and continues to be capitalism - a way of producing/reproducing social relations from the material production of social life's conditions; production based on the exploitation of labour, containing contradictions and inherent limits of its structure and dynamics (of which the latest proof, and certainly not the last, was the situation started by the financial crisis of 2008) (Coutinho 2011, 258; translation from Portuguese).

Recognising the characteristic transformations of contemporary capitalism does not imply that we no longer live in a capitalist system (nor that we have to abandon the central categories needed for its analysis. Analysing how the system itself has tried to overcome its structural crisis of the 1960s and 1970s, the Brazilian economist Marcelo Carcanholo (2011) describes a set of constitutive characteristics of contemporary capitalism: neoliberal reforms that increase surplus-value production and make way for the return to capital's profitability; the expansion of fictitious capital; the increasing transfer of surplus from the periphery to the centre, thus boosting capital accumulation in the main countries in the capitalist world economy; the expansion of markets that, with the opening up of world trade and other measures, provide new spaces for the realisation of over-accumulated capital; and the acceleration of capital turnover in production and circulation, thus increasing profit rates.

Since capitalism's crisis constitutes a situation of the overproduction and overaccumulation of capital, capital must find ways to create and expand spaces for the valorisation of this surplus capital and increased surplus-value production. One strategy for this expansion and creation of new spaces of valorisation for the capital surplus is the use of public policies for transforming public services into profitable markets. The unprecedented development of the culture industry also stands in this context and has caused a qualitative leap in the role that the media play in the ideological reproduction of capitalism.

Much of the capital invested in the service sector is directed to the culture industry, which develops enormously in the form of large communication conglomerates. Television, newspapers, magazines and the entertainment industry playing an increasingly important role in society. Such media are organised in the form of oligopo- 
lies and are used to impose neoliberalism as hegemonic discourse in the public sphere. The ideology of "self-regulating" markets' "autonomy" perspective has widely spread legitimising not only the state's economic policies but also generating a society that is deeply fragmented and individualised and in which forms of human achievement are seen as isolated and "successful projects" similar to those developed by corporations in the capitalist market.

Along with neoliberalism came the subordination of society to the logic of fictitious capital, which has also affected the realms of communication, culture and processes of consciousness formation. Carcanholo $(2010 ; 2011)$ argues that it is necessary to get back to the category of fictitious capital developed by Marx (1894) in Capital Vol. III in order to understand this process. Fictitious capital is based on a complexification of capital's typical logic: It has to do with the appropriation of value. Capital is constituted by the appropriation of surplus-value extracted from the productive process. Therefore, human labour produces value in the productive labour process and capital appropriates it.

Fictitious capital results in a relative autonomisation of the production process. At the beginning, with the development of interest-bearing capital, that process maintains a direct relation with productive labour: It takes on the form of loans so that monetary capital is invested that enables the productive process and the extraction of surplus-value. Carcanholo $(2010 ; 2011)$ points out that the generalisation of this logic is the basis of fictitious capital. A person who receives some sort of income that we call a "periodic income" - from stocks, for instance - is projected as the owner of a total amount that might not exist. In situations where the total value does not exist and is not applied in the productive process, it is still the case that this periodic income represents what that value "could be" if it was applied. The individual who has got this periodic income can sell the right to this periodic appropriation of a certain amount on the market. This sale is made taking into account the value that it would represent if it were the result of existing capital. In this way, the existence of the total amount (that generates this periodic income) is projected. Its existence is constituted by the sale of the right to its appropriation on the market, even if it does not exist at all.

However, the autonomisation of finance capital over production cannot be fully performed. Financial crises express the impossibility of this autonomisation being total or absolute. When capitalism is subordinated to the logic of fictitious capital, the dynamics of appropriation expand to production's detriment. A reduction of profit rates takes place and, in a downward cycle, capitalist crisis deepens.

Therefore, contemporary capitalism - existing under the hegemony of fictitious capital, which is characterised by "autonomisation" and an apparent detachment from the material determinations that produced it - seems to create as part of this movement representations that are so autonomised that they do not see themselves as a representation of some material referent. Generally, culture becomes a "thing-initself" that begins and ends in its own dynamics, supported by technical transformations that allow an unprecedented diffusion of its content, which expands to every layer of social life. The formation of consciousness formation and worldviews are made in direct interaction with the consumption of cultural products. The very dynamics of capital's reproducibility deepen the fetishist character of such commodities.

Fredric Jameson's (2002, 268-284) analysis of symbols is an important contribution for understanding the dynamics of the culture industry in contemporary (late) capitalism. Analysing the expansion of the logic of the commodity to the symbolic field and building on the assumptions developed by Theodor W. Adorno and Max 
Horkheimer in Dialectic of Enlightenment (1985), Jameson emphasises how forms of culture are inserted into the logic of the commodity so that exchange-value dominates over culture's use-value and cultural consumption over reflection.

The consumption of entertainment as cultural commodity tends to abandon reflection and the ability of individuals to criticise what is consumed. Reality becomes increasingly fragmented. Jameson discusses the role of the culture industry in contemporary society, where we find massive supply of cultural goods and cultural transmission at high speed. The symbolic market constitutes the space for the production, diffusion and consumption of cultural goods whose main characteristic is the fact that humanity abdicates its function as a constructor of reality and becomes a mere passive appropriator of commodities. Humans are relegated to the status of objects. Human achievement is increasingly mediated by the consumption of material and symbolic commodities so that there is a pure focus on what exists, which challenges collective consciousness' imagination and emancipatory struggles for alternative models of society.

\section{Marxism and Communication Theory: Emancipatory Praxis and the Concepts of Ideology, Alienation and Reification}

In the dynamics of the capitalist mode of production, as Marx demonstrated, every commodity assumes a 'ghostly' form and seems to take on a life of its own. In contemporary capitalism, the logic of fictitious capital deepens the appearance of the commodity's autonomy, which is especially true in the case of cultural goods. In this sense, there does not seem to be an 'outside' of dominant culture. When sociality is strongly shaped by the media and the products of the culture industry and at the same time the consumption of such material and symbolic goods means a permanent logic of legitimation of the real, then the result is the intensification and deepening of the circuits of reification and ideology that influence the formation of consciousness. Consumerism dissociates 'being informed' and 'being entertained' from the social and collective sense of praxis.

The objective reconfiguration of contemporary capitalism not only gives high importance to issues of communication and ideology, but has also resulted qualitative differentiations of consciousness and political struggles. The ceaseless supply of cultural commodities deepens ideology's 'wielding of subjectivity'. In addition to being consumed, experienced and practiced in a reified way, communication is also often perceived in fragmented ways. It is of particular interest how this process influences contemporary social movements, their communication practices and social struggles.

\section{Alienation}

For such efforts, the concept of alienation is indispensable. The theory of alienation in Marx, starting with the Economic and Philosophical Manuscripts of 1844 (Marx 1844), addresses the problems created by the transformation of labour-power into a commodity. It analyses the complex processes of estrangement of the individuals in relation to the social totality in the context of the exploitation of labour. The transformation of the human creativity into a commodity, from which the commodification of the worker itself derives, constitutes the alienation of the work process. Activities that are the creative source of human achievement become painful, exhausting, mere reproduction and a source of suffering. The result of human action appears to the worker as an exteriority that intimidates and turns against him.

Alienation results in a deep fragmentation of individuals. In capitalism, individuals produce and reproduce their lives as isolated individuals. The totality of social rela- 
tionships that is the result of human activity appears to the individuals like partial and fragmented systems. In Marx's Manuscripts, we can read:

"Till now we have been considering the estrangement; the alienation of the worker only in one of its aspects, i.e., the worker's relationship to the products of his labour. But the estrangement is manifested not only in the result but in the act of production, within the producing activity itself. How could the worker come to face the product of his activity as a stranger, were it not that in the very act of production he was estranging himself from himself? The product is after all but the summary of the activity, of production. If then the product of labour is alienation, production itself must be active alienation, the alienation of activity, the activity of alienation. In the estrangement of the object of labour is merely summarised the estrangement, the alienation, in the activity of labour itself. What, then, constitutes the alienation of labour? First, the fact that labour is external to the worker, i.e., it does not belong to his intrinsic nature; that in his work, therefore, he does not affirm himself but denies himself, does not feel content but unhappy, does not develop freely his physical and mental energy but mortifies his body and ruins his mind. The worker therefore only feels himself outside his work, and in his work feels outside himself. He feels at home when he is not working, and when he is working He does not feel at home. His labour is therefore not voluntary, but coerced; it is forced labour. [...] Lastly, the external character of labour for the worker appears in the fact that it is not his own, but someone else's, that it does not belong to him, that in it he belongs, not to himself, but to another" (Marx 1844, 274).

With the insertion of culture into the logic of commodity production, the culture industry and its commodities occupy most of the non-labour time of individuals, as Adorno and Horkheimer (1985) point out. This free time is filled with commodities that reproduce the logic of alienated labour. As a result, the dynamics of alienation in society are extended and accentuated. The configurations of contemporary capitalism deepen and complicate this process. The establishment of the symbolic market means the promotion of a quality leap in the movement of alienation. The expansion of the logic of capital into the social fabric as a whole operates by transforming qualities into quantities. Large media conglomerates quantify consciousness, knowledge, morality, sensations, desires, identities, sexuality and affects. All human subjectivity, without exception, becomes commodified, i.e. put up for sale in the symbolic market. Marx's formulations in the Manuscripts help us to see how such expansion and colonisation of the whole of social life by the logic of exchange value establishes ways of life that are clouded, partial and fragmented.

Marx's theory of alienation is not only valid for media conglomerates, but also relates to the class struggles of social movements and their efforts to construct alternative forms of society. The danger is that anti-systemic political movements that try to operate 'spontaneously' and 'horizontally' end up reproducing isolation, fragmentation and individualisation. Many analyses of the social movements and protests that emerged globally since the beginning of 2011 in the context of the sharpening of the capitalist economic crisis, have highlighted the role played by communication technologies (especially social media). Some of the common characteristics of the communication practices developed, for example, by the movements during the mobilization processes in Tunisia (2011), Spain (2011/2012) and Brazil (2013) reaffirm alienation by advancing individualism and fragmentation. 
One ideological idea is that social movements' questioning of how the discourse of large media conglomerates tries to criminalise and badmouth social protests is a spontaneous and horizontal communication process. Studies have shown that communication in social movements is not horizontal, but that there are groups of activists who are particular tech-savvy, take a leadership role and "choreograph" assemblies and their communication processes (Gerbaudo 2012; Fuchs 2014). The claim that individuals form independent opinions and produce and consume information in a self-determined manner independent from each other and without hierarchies (hence the talk about 'Twitter revolutions' and 'Facebook protests') ends up reaffirming alienation. The Marxist theory of alienation helps us to see how the fragmented interaction of individuals reaffirms their subjugation to the real. Symbolic production that ignores such mechanisms risks to reproduce these dynamics.

István Mészáros $(2006,166)$ points out that the richness of the Marxist theory of alienation lies in the fact that it is not mechanistic or rigid, but inherently dynamic. Alienation does not inscribe a closed and impenetrable circuit between alienated labour and the self-alienation of consciousness. There are spaces for overcoming the historical conditions of alienation. Alienation produces not only alienated consciousness, but also the contradictions that allow the consciousness of being alienated. Overcoming alienation presupposes a totalising and collective praxis rather than a sum of fragmented and isolated experiences of individuals atomised by capitalist sociality. The Marxist theory of alienation provides a series of fundamental contributions for understanding meanings and practices of communication in anti-systemic movements. The conditions of alienation can only be overcome by a totalising rupture that must include a transformations of the social relations of production. Such a fundamental change that aims at building historical alternatives must also incorporate symbolic struggles.

\section{Ideology}

Also the concept of ideology can inform contemporary communication theory and the relation of communication, consciousness and social movements. Marx and Engels (1845/46) in The German Ideology discuss the notions of false consciousness and mystification that are relevant for understanding the topic under discussion.

The classical meaning of ideology in Marx and Engels is that ideologies are distorted representations of a "distorted" reality. Ideology critique seeks to understand how from material relations of production based on alienated work emerge structures that legitimise such relations of production. Ideas become distorted by being presented and perceived in a way that is dissociated from their historical context. The conditions they represent appear as natural and ahistorical. More than simple and intentional lies, ideology is an expression of a particular consciousness that manifests material relations.

"Division of labour only becomes truly such from the moment when a division of material and mental labour appears. From this moment onwards consciousness can really flatter itself that it is something other than consciousness of existing practice, that it really represents something without representing something real; from now on consciousness is in a position to emancipate itself from the world and to proceed to the formation of 'pure' theory, theology, philosophy, morality, etc." (Marx and Engels 1845/46, 45) 
Ideology is constituted by mechanisms of inversion that dissociate ideas from history and present forms of domination as truths that are independent from society's contradictions. Understanding the role of such ideological forms of inversion and mystification in the production of discourses and cultural goods is a fundamental aspect of the critical cultural analysis. Marx and Engels $(1845 / 46,59)$ demonstrate that "the ideas of the ruling class are in every epoch the ruling ideas: i.e. the class which is the ruling material force of society, is at the same time its ruling intellectual force". Ideas that represent bourgeoisie's interest naturalise the class relations of capitalism. Capitalism is taking the absolute starting point of any society so that it is affirmed as a way of life. At the same time, this does not mean that bourgeoisie thinkers cannot come to relevant conclusions regard specific phenomena within this structural limitation.

The concept of ideology allows us to relate the production of meanings in communication processes to class relations and political interests. Ideology demystifies what is presented as universal by the ruling class and thus opens up perspectives for an uncolonised symbolic production and material structures underpinning it. At the same time, the concept of ideology allows us to question claims that antisystemic communication and political practices are mere "narrative disputes". One needs to see that narratives and discourses are deeply embedded into and shaped by material interests.

The danger of seeing communication as independent from material structures is that one does not consider systemic alternatives necessary and reduces political praxis to mere dispute expressed as narratives, discourses or subjective attitudes in the current world. In The German Ideology, Marx and Engels (Ibid., 24) use the metaphor of the "valiant fellow" who "had the idea that men were drowned in water only because they were possessed with the idea of gravity" to criticise the philosophical method of the young Hegelians. They point out the ideological character of attempts to solve concrete contradictions by simply combating their representations. Contemporary "valiant fellows" focus on "narrative disputes" as the main horizon of communication in the current social movements. They end up focusing solely on representations and do not place questioning the material referent of culture at the centre of praxis.

\section{Reification: Subjectivity as a Commodity and the Social Movement as a Mar- ket}

Also the notion of reification is important for understanding society, politics and culture today. The logic of dehumanisation works via the symbolic market and constitutes a qualitative leap in contemporary capitalism. The link between neoliberalism, the culture industry and neoliberal ideology promotes the deepening of the process of reification that occurs at any stage of the development of capitalist society. The concept of reification can help us to think critically about the relationship between social movements and the production of communication. It can help us overcome the liberal frameworks that dominate the analysis of the communicative process.

Contemporary social movements often claim that their political goal is to increase the diversity of communication, to multiply voices and to be a mosaic of multiplicities and multiple partial interests. The Ninja Media Collective (Mídia Ninja), a group of alternative journalists, advanced such arguments in the 2013 Brazilian protests. The problem is that communication is framed from within liberal perspectives.

In such perspectives, the formation of consciousness is part of an essentially individual movement, where the collective is a mere sum of individuals and there is no 
collective project. The role of communication is reduced to the construction of multiple subjectivities that are as diverse as possible, so that individuals can position themselves in the world. Here we can find exactly the capitalist logic that should be overcome: communication and consciousness appear to construct a democratic 'competitive market' of opinions and worldviews.

In such a mosaic market of subjectivities, the ultimate parameter is the individual as consumer who chooses opinions like commodities in a supermarket shelf and not the collective subject. The concept of reification helps us to criticise this uncritical introjection of the logic of the commodity. Reification appears in the construction of neoliberalism as a generality that derives from a series of partial elements. The reification of social relations and their representations makes domination and exploitation as an objective law that is external to human production.

Individuals establish specific social relations that under the conditions of alienation appear to them as having character of objective laws that cannot be questioned and changed. Social relations, then, are accepted as undoubted 'duty'. In the process of reification, the relations between the various partial systems, between each specific reality, appear to be produced by these partial systems, due to a principle that is internal to them. Thus, the final system, the totality, appears as a formality, not a set formed of material determinations and contradictions with its own dynamics. The concrete totality of the social process, which determines each of its parts, is in the consciousness of individuals replaced by a formal totality that seems to result from intersubjective interactions.

The abolishment of capitalist logic requires the connection of the processes of formation of consciousness with the production of social significations that could overcome the isolation of individual perception through constitution of a collective political subject in a collective and historical political project. This task demands transcending the barriers of symbolic and subjective production by relating subjectivity to the material relations and contradictions of society. Marxism makes indispensable contributions to this political task.

\section{References}

Adorno, Theodor and Max Horkheimer. 1985. Dialética do Esclarecimento: Fragmentos Filosóficos. Rio de Janeiro: Jorge Zahar Ed.

Carcanholo, Marcelo. 2011. Conteúdo e Forma da Crise Atual do Capitalismo: Lógica, Contradições e Possibilidades. Crítica e Sociedade 1 (3): 73-84. Accessed January 22, 2018. http://www.seer.ufu.br/index.php/criticasociedade/article/viewFile/14551/8279

Carcanholo, Marcelo. 2010. Crise Econômica Atual e seus Impactos para a Organização da Classe Trabalhadora. Aurora ano IV. Accessed January 22, 2018. http://www.marilia.unesp.br/Home/RevistasEletronicas/Aurora/1\%20CARCANHOLO.pdf

Coutinho, Carlos Nelson. 2011. O Estruturalismo e a Miséria da Razão. São Paulo: Expressão Popular.

Fuchs, Christian. 2014. OccupyMedia! The Occupy Movement and Social Media in Crisis Capitalism. Winchester: Zero Books.

Gerbaudo, Paolo. 2012. Tweets and the Streets: Social Media and Contemporary Activism. London: Pluto.

Jameson, Fredric. 2002. Pós Modernismo: a Lógica Cultural do Capitalismo Tardio. São Paulo: Editora Ática.

Marx, Karl. 1894. Capital: A Critique of Political Economy: Volume Three. London: Penguin. Marx, Karl. 1844. Economic and Philosophic Manuscripts of 1844. In MECW Volume 3, 229346. London: Lawrence \& Wishart. 
Marx, Karl and Friedrich Engels. 1845/46. The German Ideology. In MECW Volume 5, 19 539. London: Lawrence \& Wishart.

Mészáros, István. 2006. A Teoria da Alienação em Marx. São Paulo: Boitempo.

Netto, José Paulo, ed. 1981. Georg Lukács. São Paulo: Ática.

\section{About the Author}

\section{Leila Salim Leal}

Leila Salim Leal is a journalist who holds a PhD in Communication and Culture (2017) by the Post-Graduate Programme in Communications and Culture of the Federal University of Rio de Janeiro (UFRJ), Brazil. She conducts research on the interfaces between communication, culture and postmodernity in contemporary capitalism and its expressions in the culture industry; the crisis of capitalism, the project of capital for the reordering of cities and contemporary social movements in the context of the media and culture. She was substitute professor at UFRJ's School of Communication between 2015 and 2017 and is a researcher in the Group of Marxist Studies in Communication and Culture (Gemccult) at UFRJ. 